\title{
Tinjauan Yuridis Tentang Peralihan Hak Atas Tanah yang Akan Digunakan Untuk Jalan Tol Trans Sumatera (Studi Pada BPN Lampung Selatan)
}

\author{
Muhammad Alif Rizqi \\ Universitas Bandar Lampung \\ Jl. ZA Pagaralam No 26 Bandar Lampung \\ Correspondence email: muhammadalifrizqi@gmail.com
}

\begin{abstract}
Abstrak. Tanah merupakan elemen penting yang ada dalam kehidupan sehingga berguna untuk kehidupan umat manusia. Pemerintah mengeluarkan peraturan dalam hal peralihan hak atas tanah yaitu: Peraturan Pemerintah Nomor 10 Tahun 1961 tentang pendaftaran tanah diubah dengan peraturan nomor 24 Tahun 1997 tentang pendaftaran tanah yang dimuat pada pasal 37 ayat 1 yang berbunyi "pemindahan hak atas tanah dalam hak milik satuan melaluli jual beli, tukar-menukar, hibah, pemasukan dalam perusahaan dan perbuatan pemindahan hak lainnya, kecuali pemindahan hak lelang yang hanya didaftarkan jika dibuktikan adanya akta yang sudah dibuat oleh PPAT". Dalam peralihan hak atas tanah ada 2 bentuk yaitu: beralih dan diahlikan. dan Peraturan Presiden tersebut kemudian Presiden ke tujuh Indonesia yaitu bapak Joko Widodo memperbaiki peraturan tersebut dengan dikeluarkannya Peraturan presiden Nomor 117 Tahun 2015 tentang Perubahan atas Peraturan Presiden Nomor 100 Tahun 2014 tentang Percepatan Pembangunan Jalan Tol di Sumatera yang segera ditambah dengan menjadi total 24 pembangunan ruas tol Sumatra. dalam penulisan jurnal ini penulis membahas dua masalah yaitu: Bagaimana implementasi terhadap peralihan hak atas tanah yang akan digunakan untuk jalan tol dan Apa dampak terhadap warga yang menolak Tanah nya untuk dijual dan digunakan untuk kepentingan umum terkait pembangunan jalan tol?
\end{abstract}

Kata Kunci: Tinjauan Yuridis, Peralihan Hak Atas Tanah, Peralihan Hak Atas Tanah.

Abstract. Soil is an important element in life especially for humans. In the transfer of land rights, the government issued regulations, namely: Government Regulation Number 10 of 1961 concerning land registration amended by regulation number 24 of 1997 concerning land registration contained in article 37 paragraph 1 which reads "transfer of rights to land in unit property rights through sale and purchase. , exchanges, grants, income in the company and other acts of transfer of rights, except the transfer of auction rights which are only registered if it is proven that there are deeds that have been made by PPAT ". There are two forms of transfer of land rights, namely: transfer and diahlikan. and the Presidential Regulation was then revised by the seventh President of Indonesia, Mr. Joko Widodo with the issuance of Presidential Regulation Number 117 of 2015 concerning Amendments to Presidential Regulation Number 100 of 2014 concerning the Acceleration of Toll Road Development in Sumatra which will soon be added to a total of 24 Sumatra toll road developments. In writing this journal, the author discusses a problem, namely: How is the implementation of the transfer of land rights to be used for road telling?

Keywords: Juridical Overview, Transfer of Land Rights, Transfer of Land Rights.

\section{PENDAHULUAN}

Tanah merupakan masalah kehidupan, berbagai man faat yang menyertainya memb erikan banyak manfaat bagi ma nusia, saat ini kebut uhan Untuk lahan sangat penting terutama di wilayah metropolitan, hal ini disebabkan dan dipengaruhi oleh pertumbuhan penduduk yang kuat, selain itu, faktor lain dapat memicu hal tersebut. tersebar luas di ko ta-kota besar. Oleh karena itu, tidak jar ang masyarakat saat ini membeli tanah un tuk kawasan yang dekat dengan kota besar. Hal tersebut menjadikan pembangunan jalan tol sebagai salah satu solusi permasalahan di kota-kota besar.

Pengertian pengalihan hak atas tan ah, yaitu pengalihan hak atas ta nah dari orang tua atau peme gang hak kepada peme gang hak baru, pengertian ini dicantumkan dan telah diatur dalam ketentuan peraturan perundangundangan yang berlaku, yaitu: Keputusan Pemerintah No. 10 tahun 1961 berkaitan dengan daftar tanah yang diubah dengan SK No. 24 tahun 1997 tentang pendaftaran dalam daftar tanah dalam Pasal 37 ayat 1, yang berbunyi: "Pengalihan hak atas tanah atas kepemilikan hak atas tanah melalui jual beli, tukar menukar, konsesi, merger menjadi perusahaan dan tindakan pengalihan hak lainnya, kecuali pengalihan hak pengalihan, yang hanya didaftarkan jika ada bukti bahwa dokumen PPAT tersedia." 1

Ada dua bentuk pengalihan hak atas tanah: pengalihan dan amandemen. artinya pengalihan hak atas tanah tanpa adanya kebingungan hukum dengan pemiliknya, misal prem. Pemilik hak atas tanah telah diwariskan dan

${ }^{1}$ Hukum Perencanaan Pembangunan 2 tahun 2012 tentang Pengadaan Tanah untuk Pembangunan untuk Kepentingan Umum 
diperuntukkan bagi ahli waris, sedangkan pengalihan hak atas tanah adalah sah dari pemilik hak atas tanah dengan dukungan dari pemegang hak atas tanah, misalnya pembelian dan penjualan. ${ }^{2}$

Belakangan ini kebutuhan akan tanah di Indonesia sangat tinggi. Hal ini disebabkan banyaknya masyarakat Indonesia yang menginginkan atau membutuhkan lahan untuk membangun perumahan, dan bukan hanya karena kebijakan pemerintah untuk membangun infrastruktur khusus jalan tol membutuhkan sebagian lahan milik masyarakat., Khususnya tol Trans Sumatera, Lampung Selatan Kabupaten. ${ }^{3}$

Pada tahap awal perencanaan pembangunan jalan tol yaitu di pulau Sumatera tidak banyak diminati oleh berbagai investor asing maupun lokal, sehingga presiden keenam Indonesia saat itu harus mengeluarkan Keputusan Presiden No. 100 Tahun 2014 sehubungan dengan percepatan pembangunan jalan tol di Sumatera pada 17 September 2014.

Dalam Peratutran, Presiden menyebutkan bahwa pemerintah akan melanjutkan pembangunan Jalan Tol langsung dari Me dan -Bin jai Palemb ang -Simpang Indra laya, jalan Pekan baru, dan jalan lain dari Dumai dan jalan lain dari jalan tol Bakauheni dan Terbanggi. Peraturan Presiden ini kemu dian dire visi oleh Presiden Ketujuh Indonesia, Bapak Joko Wid odo, dengan dikeluarkannya Perat uran Presiden No. 117 Tahu n 2015 yang mengubah Peraturan Presiden No. 100 tahun 2014 untuk perce patan perluasan jalan tol di Sum atera yang akan segera ditambah menjadi total 24 proyek tol. Sumatera.

Pada 30 April 2015, konstruksi dimulai dengan peletakan batu pondasi untuk pembangunan tol Baka uheniTerbanggi Be sar oleh Presi den Joko Widodo. Peresmian jalan tol dila kukan sec ara bertahap, peres mian tahap pertama dilak ukan pada tanggal 21 Jan uari 2018 yang meliputi Pelab uhan Bakauheni-Simp ang Susun Bakauh eni sejauh 8,9 km dan Lematang di Simp ang Susun Kota baru sejauh 5,64 km. Jal an tol tersebut dires mikan secara pen uh pada 8 Maret 2019.

Perencanaan Tol Dalam pembangunan jalan tersebut, pemerintah membutuhkan dukungan dari masyarakat, khususnya masyarakat Lampung Selatan yang lahannya digunakan untuk warga sekitar. Jalan tol untuk memfasilitasi pengalihan hak atas tanah kepada negara.

Alasan penulis menyusun jurnal ini adalah untuk menyelidiki pengalihan hak atas tanah pada jalan tol Trans Sumatera. Penulis berpendapat bahwa pengalihan hak atas tanah dapat dilakukan ketika pemegang hak atas tanah pertama kali meminta bantuan hukum untuk pengalihan hak atas tanah. karena jalan tol sumatera sendiri merupakan program pemerintah, maka dari itu program pemerintah tersebut harus didukung oleh pemerintah kota atau badan yang berwenang dalam hal ini Badan Pertanahan Nasional yang menyelenggarakan kegiatan dan membawahi program pemerintah yaitu pembangunan Sumatera. Jalan TRANS.

\section{METODE}

Penulis menggunakan pendekatan yuridis normatif dan empiris:

Metode yuridis normatif merup akan pendek atan yang didasarkan pada materi hu kum utama dengan meng kaji teori, konsep, prinsip huk um dan peraturan peru ndang-undangan yang relevan den gan penelitian ini. Berikut penjelasan kasus ini dalam konteks kasus yuridis normatif:

Metode yuridis empiris adalah aturan dasar pertanian, yang mengatur-Hukum-hak atas tanah, air dan udara, diperoleh secara langsung melalui wawancara atau langsung di lapangan.

\section{HASIL DAN PEMBAHASAN}

\section{Implementasi Terhadap Peralihan Hak Atas Tanah Yang Akan Digunakan Untuk Jalan Tol}

Berdasarkan informasi atau artikel yang dibaca penulis, proyek JTTS (Jalan Tol Trans Sumatera) sedang dalam pengerjaan sepanjang $643 \mathrm{~km}$. Ruas tersebut diharapkan akan selesai pada akhir tahun 2022. "513 km saat ini sedang digunakan, dan $643 \mathrm{~km}$ sedang dalam pembangunan. Sebanyak $1.156 \mathrm{~km}$ telah selesai dan sedang dibangun. Rencananya JTTS ini akan menjadi peta pertama yang menjadi jalan tol pada akhir tahun 2022.

Bersamaan dengan itu, juga ada rencana tahap kedua yang saat ini sedang memasuki proses pembebasan lahan. Bagian yang memasuki fase ini meliputi dari Bet ung, Palem bang, Jambi, hingga Pekan baru. Panjang totalnya adalah 570 km. Ini harus sele sai pada akhir 2023. "Kemudian tahap ketiga dari Dumai ke Medan. Lalu Medan ke Aceh. Tahap ke tiga akan selesai pada 2024."

Konon Hutama (HK) sa at ini sedang fokus untuk percepatan Perkembangan tulang punggung atau jalannya Menurut dia, langkah ini sejalan dengan arahan Menteri UPPR Bas uki Hadim uljono dan Menteri BUMN Eri ck Thohir: "Ke depan kita akanfokus pada tulang punggung. Artinya jalur utama dari Bak auheni ke Palembang sudah

${ }^{2}$ No. Pemerintah 10 Tahun 1961 tentang Pendaftaran Tanah

${ }^{3}$ PeraturanHandayani, Mei Fatul dkk., "Pengaruh Pembebasan Lahan Jalan Tol Surabaya Mojokerto (Sumo) terhadap Kualitas Hidup Mantan Pemilik Tanah à Sumberwaru, Wringinom-Gresik”, Jurnal Universitas Pembangunan Nasional, Volume 5 No.2, Desember 2016 
terkoneksi. Tugas kita selanju tnya adalah menyambung. dari Palembang, Jambi, Peka nbaru. Kemudian Peka nbaru Dum ai mulai bero perasi."

Lalu lanjutkan ke Du mai - Kisaran. Kemu dian Kisaran-Indra pura sedang diban gun dan kemudian dihubungkan den gan Indrapura-Med an yang merupakan jalan tol lama. Kem udian dia pergi dari Me dan ke Binjai. Binjai ke Lan gsa. Untuk Aceh ...

Berdasarkan bukti-bukti yang dipaparkan diatas, penulis meyakini bahwa pelaksanaan jalan raya Trans Sumatera tiga undak, tahap pertama di area seluas $643 \mathrm{Km}$ pada area seluas $513 \mathrm{Km}$ dengan target selesai tahun 2022. Tahap kedua adalah proses saluran pembuangan, Palembang, Jambi dan Kemiri. Baru di wilayah $570 \mathrm{~km}$ akan selesai pada 2023, sedangkan Tahapan penyelesaian ketiga dijadwalkan 2024 Masih belum ada kepastian ketahanan ketiga bisa tercapai ketika tol Trans-Sumatera selesai.

\section{Dampak Terhadap Warga Yang Menolak Tanah Nya Untuk Dijual Dan Digunakan Untuk Kepentingan Umum Terkait Pembangunan Jalan Tol}

Pembangunan Tra ns Sumatera Divisi jala n tol Medan-Binjai tol Palem bang-Simpang Indr alaya, tol Pekan Baru-Du mai dan salah satunya tol Baka uheni dan Terba nggi Besar, Kabupaten Lampung Selatan berdampak pada tata guna lahan perubahan komunitas yang mempengaruhi jalan tol yang mempengaruhi komunitas sosial.

Dalam proyek pembangunan ini, tanah bersama, yang berfungsi seba gai lokasi pemba ngunan jal an tol, berarti pemerintah kota harus men cari lokasi baru di atas tanah ini sebagai tempat tinggal dan permintaan tanah kota meningkat karena pembangunan jalan tol. jalan tol. Produksi lahan pertanian kini digunakan sebagai cara untuk memenuhi kebutuhan lahan. Hal ini mendorong orang untuk mencari tempat tinggal baru, yang secara tidak langsung menyebabkan hasil yang lebih rendah daripada pertanian komunal.

Berdasarkan ketentuan Undang-Undang Nomor 5 Tahun 1960 tentang Pokok-pokok Pokok Pertanian, namun mengatur hak atas tanah, air, dan udara pada saat kepentingan umum menghendaki dan dapat dipertanggungjawabkan dalam keadaan tertentu; Studi kelayakan strategis selesai, properti dilepaskan. Oleh karena itu, pengalihan hak atas tanah memang diperbolehkan selama itu untuk kepentingan umum bagi pembangunan dan memb erikan man faat makroeko nomi. Tidak hanya secara ma kro ekonomi, tetapi juga man faat langs ung dari pengalihan hak atas tanah dan juga penciptaan kawasan perumahan baru dalam rangka mendukung masyarakat sehingga berpotensi untuk maju dan melahirkan titik-titik massa baru.

Akibat-akibat berikut ini terjadi ketika tanah warga digunakan untuk kepentingan umum:, Penelitian menunjukkan bahwa warga

\section{Dampak positif}

1. Pengurangan kemacetan Jika warga tidak menolak jalan tol yang akan dibangun akan menerima apartemen sebagai imbalan atas pengalihan tanah milik Sumtera - Warga dan di hadapan jalan raya. Tol bisa mengurangi masalah kemacetan. Terlihat juga dari pantauan jalur Trans Sumatera yang juga merupakan daerah asal para penjelajah melihat hal tersebut. Kenda raan yang mele wati Jalan Tol Sum atera mengalami penurunan dan ban yak yang mele wati jalan tol tersebut sehi ngga mengaki batkan beberapa pembeli terlantar. .

2. Jalan alternatif menjadi jal an tol Jalan alter natif yang dapat digun akan mendapatkan respon yang positif. Jal an tol merupakan jal an yang masih dapat digu nakan kendaraan pribadi maupun umum untuk mengefisienkan waktu tempuh. Namun dalam studi ini, beberapa pihak menanggapi secara negatif bahwa jalan tol tersebut bukan merupakan jalan alternatif yang masih dapat digunakan, karena hanya masyarakat menengah ke atas dan masyarakat yang melakukan perjalanan antar daerah yang dapat menggunakan fasilitas ini, begitu pula dengan operator pelayaran yang mendapatkan keuntungan. dan untuk masyarakat. Kecil dan tentunya tidak mendapatkan keuntungan dari zona tol.

3. Memper mudah pendistri busian barang Den gan dibangunnya jalan tol maka pendistr ibusian barang menjadi lebih menguntungkan dalam waktu dan uang, yang berdampak positif pada tingkat makroekonomi.

4. Hasil penelitian menunjukkan bahwa pemban gunan jala $\mathrm{n}$ tol akan mendorong pertum buhan ekonomi di berba gai daerah. Hal ini menunjukkan bahwa keper cayaan masy arakat terhadap pemban gunan akan berdampak posit if pada skala tol skala makro, termasuk dalam program pemerintah yang mempromosikan kawasan tersebut.

\section{Dampak negatif}

1. Tidak menciptakan kesetaraan ekonomi Pembangunan jalan tol yang tentunya memberikan manfaat yang luas, terutama pemerataan ekonomi, kurang diterima secara positif oleh masyarakat karena persepsi masyarakat tentang kesetaraan ekonomi kurang positif dan pihak yang setuju dengannya serta berpendapat bahwa hal tersebut dipengaruhi oleh Pemba ngunan jalan tol yang hanya mend apat UGR, sisa keunt ungan sebagian besar didapat oleh operator pelayaran dan masyarakat menengah ke atas. 
2. Kebutuhan pokok belum berkurang Dari segi kegiatan ekonomi, dimana pembangunan jalan tol memastikan kelancaran proses, memperc epat waktu tem puh memang menghe mat waktu dan biaya, namun harga sembako tidak turun, begitu pula tanggapan responden yang berbuat lebih. orang tid ak setuju dengan perny ataan kebut uhan dasar untuk terjangkau.

3. Pengurangan tanah ulayat Pemb angunan jalan tol Trans Suma tera di atas selu as $\pm 14.335,91$ hektar (ha) digunakan sebagai pembebasan lahan untuk pembangunan kepentingan umu m. Dari hasil obse rvasi dan kuisioner dapat dijelaskan bah wa proses pembebasan lahan di wilayah Bakauheni hingga yang paling signifikan berdampak pada perubahan penggunaan lahan untuk permukiman produktif yang digunakan dalam pemb angunan jalan tol. Nam un hal ini tidak dap at dihindari karena perkembangan mikroekonomi dari pengurangan lahan akan menguntungkan dan beberapa akan merugikan. Namun pembangunan untuk kepentingan umum sebagaimana diuraikan dalam proposal penelitian sebelumnya harus dilakukan sedemikian rupa sehingga tanah tersebut digunakan untuk berbagai kegiatan pembangunan sesuai dengan sifat fisik tanah tersebut, sehingga dapat tercapai kelebihan dan manfaat. sambil menghormati kelestarian lingk ungan dan, ked ua, di bidang keanekaragaman, ya itu memastikan peng uasaan dan kepemilikan tanah dan pengalihan hak atas tanah.

Berdasarkan uraian di atas, penulis menyimpulkan bahwa manfaat penggunaan lahan Lampung Selatan sebagai jalan tol akan mengurangi kemacetan, menjadi jalan alternatif, memperlancar distribusi, dan menjadi penggerak perekonomian yang efektif dan efisien. Dampak negatif tidak akan menimbulkan perekonomian. pemerataan, pengurangan kebutuhan ekonomi dasar penduduk dan pengurangan luas tanah bersama karena pemerintah lebih memperhatikan kerugian penduduk Lampung Selatan.

\section{SIMPULAN}

Pada tahap ini, kebutuhan lahan sangat tinggi, terutama di wilayah perkotaan besar. dan dalam hal pengalihan hak atas tanah, yang melibatkan pengalihan hak atas tanah dari orang tua atau pemegang hak kepada pemegang hak baru, definisi ini sendiri didukung oleh Keputusan Presiden, yang kemudian diubah dengan Presiden Ketujuh Indonesia. Bapak Joko Widodo dengan dikeluarkannya Peraturan Presiden Nomor 117 Tahun 2015 yang mengubah Peraturan Presiden Nomor 100 Tahun 2014 tentang Percepatan Pembangunan Jalan Tol di Sumatera yang akan segera ditambah menjadi total 24 pemba ngunan jala $n$ tol. di Suma tera. Pada artikel kali ini penulis menarik kesimpulan berdasarkan permasalahan yang ada yaitu bagaimana peman faatan lahan rakyat yang akan digun akan untuk pembangunan jal an tol Sumatera di Lampung Selatan dan apa dampak yang akan ditimbulkan terhadap masyarakat jika hak milik mereka dimilikinya. dilakukan. . yang mengikuti uraian pada bab pembahasan yang dijelaskan oleh penulis.

\section{Saran}

Dalam membangun jalan tol di Sumatera, pemerintah harus lebih berhati-hati jika ada masyarakat yang tidak mampu meredistribusi perekonomian atau jika ada yang merugi jika tanahnya diambil untuk kepentingan umum atau disita. dan pemerintah juga harus mempertimbangkan prospek mempertimbangkan relokasi asrama. Jika selama relokasi atau dalam proses pemukiman kembali tidak ada kesulitan dengan warga, pemerintah berhasil menjalankan program kerja pemerintahnya, namun jika tidak berhasil, beberapa warga memprotes. Program kerja pemerintah, pemerintah perlu mempertimbangkan kembali bagaimana menangani masalah tersebut. Untuk menghindari permasalahan penduduk sekitar Lampung Süd yang lebih umum dan dibahas oleh penulis.

Saat mengalihkan hak atas tanah, orang pertama akan meminta bantuan hukum untuk mengalihkan hak atas tanah karena Jalan Tol Sumatera sendiri merupakan program pemerintah. Oleh karena itu, program pemerintah harus didukung oleh masyarakat, atau instansi yang berwenang dalam hal ini Badan Pertanahan Nasional, yang secara bersamaan melakukan kegiatan dan mengawasi program pemerintah yaitu pembangunan Jalan TOl TRANS Sumatera.

\section{DAFTAR PUSTAKA}

Adisasmita, H. Rahardjo, Pembangunan Ekonomi Kota, Yogyakarta: Graha Ilmu 2005

Adisasmita, Rahardjo, Ekonomi Antariksa Daerah, Yogyakarta: Arsip Sejarah Graha Ilmu 2014

HM Burhan, Sosiologi Komunikasi, Jakarta: Kencana 2006

Ermando, Muhammad Nurman Sasono dan Cahyono Susetyo, "Analisis Kemungkinan Perubahan Penggunaan Lahan Berdasarkan Model Spasial Harga Tanah di Jombang", Jurnal Teknik ITS, Vol. 3, tidak. 6, tidak. 2, 2017

Handayani, Mei Fatul dkk., "Pengaruh Pembebasan Lahan Pertanian Jalan Tol Surabaya Mojokerto (Sumo) terhadap Kualitas Hidup Mantan Pemilik Tanah à Sumberwaru, Wringinom - Gresik”, Jurnal Universitas Pembangunan Nasional, Vol 5 No.2, Desember 2016

Hariyati, Sinta, "Persepsi Masyarakat Terhadap Pembangunan Jembatan Mahkota Ii di Kota Samarinda", Jurnal Sains Pemerintah, Volume 3 No.2, 2015 
Muhammad Alif Rizqi, Tinjauan Yuridis Tentang Peralihan Hak Atas Tanah yang Akan Digunakan Untuk Jalan Tol Trans Sumatera (Studi Pada BPN Lampung Selatan)

Hartanto, Abdul Aziz Hartanto dan Wisnu Pradoto, Pengaruh Jalan Tol perkembangan perubahan pola tata ruang dan struktur di kawasan Sidomulyo Timur, Ungaran, Jurnal PWK Teknik, Volume 3 No 4, 2014

Hartati, Dwi Rini dan Wirawan Widiyanto, Persepsi umum perubahan tata guna lahan dalam pembangunan Selat Sunda, Jurnal Pekerjaan Sosial dan Pekerjaan Umum, Volume 7 No. 2, Juli 2015

Harum, Muhammad dan Sutriani, "Pengaruh Pembangunan Jalan Tol Sutami Terhadap Nilai Tanah Sekitar", Jurnal Teknik, Vol. Me 4, No. 1, 2017

TOL UU Jalan No. 15 tahun 2005 No. 2 tahun 2012 tentang Akuisisi Ta nah Untuk Tujuan Pembangunan untuk Kepentingan Umum Republik Indonesia No. 38 Tahun 2004 UU Jalan-Republik Indonesia No. 25 Tahun 2004 Sistem 